\title{
Bisalbuminemia: A Pathologist's Insight of an Uncommon Phenomenon
}

\author{
Gargi Kapatia ${ }^{1}$ Monika Wadhwa ${ }^{2}$ Pankaj Malhotra ${ }^{2}$ Gaurav Prakash¹ Ritu Aggarwal ${ }^{1}$ \\ ${ }^{1}$ Department of Immunopathology, Postgraduate Institute of \\ Medical Education and Research, Chandigarh, India \\ ${ }^{2}$ Department of Internal Medicine, Postgraduate Institute of \\ Medical Education and Research, Chandigarh, India

\begin{abstract}
Address for correspondence Ritu Aggarwal, MD, Department of Immunopathology, Postgraduate Institute of Medical Education and Research (PGIMER), Chandigarh 160012, India (e-mail: ritu_immunopath@yahoo.co.in).
\end{abstract}

J Lab Physicians 2021;13:219-223.

\begin{abstract}
Keywords

- gel electrophoresis

- albumin

- serum protein

electrophoresis

Background The incidence of a bifid electrophoretic pattern in the albumin region on serum protein electrophoresis is an infrequent phenomenon. The availability of literature from India is scarce and is limited to case reports.

Objective The aim of the study is to analyze the frequency of bisalbuminemia in an Indian referral facility. The study delved into their clinical associations.

Material and Methods The retrospective case records of the patient from the departmental database were scrutinized. The study subjects were for an 8-year study period.

Results There were about 39,900 serum electrophoresis performed in an 8-year study period. A total of 40 cases of bisalbuminemia were detected. The incidence in our cohort was $0.01 \%$.

Conclusion Bisalbuminemia, an overtly benign condition, is infrequent in Indian population although not rare. It is associated with several clinical disorders; however, the association seems to be plausibly coincidental.
\end{abstract}

\section{Introduction}

Human serum albumin (HSA) is a vital constituent of human plasma with a variety of physiological functions. Besides being essential, HSA constitutes 60 to $65 \%$ of total plasma proteins. ${ }^{1}$ HSA's role in maintaining oncotic pressure is well known. In addition, HSA helps in transportation of several endogenous and exogenous molecules. ${ }^{2}$ Its antioxidant function protects the body from several oxidizing agents. It acts as catalyst in various body reactions. ${ }^{2}$ It is produced in the liver by hepatocytes as a $66.5 \mathrm{kDa}$ single polypeptide chain and is secreted into plasma without glycosylation. Structurally, it is comprised of 585 amino acid residues with $67 \% \alpha$-helix and without $\beta$-sheet. It has three homologous domains and each domain is further comprised of two subdomains (A and B). ${ }^{3}$

published online June 16, 2021
DOI https://doi.org/

$10.1055 / \mathrm{s}-0041-1730878$ ISSN 0974-2727
Serum protein electrophoresis (SPEP) is an investigative procedure which is performed routinely for diagnostic purpose, specifically as a screening test for monoclonal gammopathies. However, we come across infrequent samples which have two bands in the albumin region on the agarose gel electrophoresis and this pattern is termed as bisalbuminemia or alloalbuminemia. This phenomenon was first described in the year 1955 by Scheurlen in a diabetic German patient. This gives rise to two separate albumin peaks because of their dissimilar mobilities on SPEP. ${ }^{4}$ The incidence of these variants is usually stated to be $1: 1000$ to $1: 3000{ }^{1}$ The incidence is reported to be high $(1: 100)$ in several tribes of North American Indians. ${ }^{5}$ In this study, we wanted to evaluate the frequency of bisalbuminemia among patient undergoing screening in our laboratory. As immunopathologists, (c) 2021. The Indian Association of Laboratory Physicians.

This is an open access article published by Thieme under the terms of the Creative Commons Attribution-NonDerivative-NonCommercial-License, permitting copying and reproduction so long as the original work is given appropriate credit. Contents may not be used for commercial purposes, or adapted, remixed, transformed or built upon. (https://creativecommons.org/licenses/by-nc-nd/4.0/). Thieme Medical and Scientific Publishers Pvt. Ltd. A-12, 2nd Floor, Sector 2, Noida-201301 UP, India 
we were inquisitive regarding its translational importance. Hence, in the present study in addition to frequency, we tried to analyze the disease association in a cohort of patient with bisalbuminemia.

\section{Materials and Methods}

The study presents retrospectively analyzed data from departmental case records and meets the conditions of the World Medical Association Declaration of Helsinki. This study includes 40 cases of bisalbuminemia diagnosed on SPEP. In the present study, we included all electrophoretically diagnosed cases of bisalbuminemia $(n=40)$ in the Department of Immunopathology of Postgraduate Institute of Medical Education and Research (PGIMER), Chandigarh from January 2012 to December 2019. SPEP was conducted with agarose gel electrophoresis on Helena Bioscience (Europe) platform. The kits utilized for running the test were SAS-1 plus and SAS-2 SAS-1SP 24 SB kit. ${ }^{6}$ The proteins were separated on the gel on the basis of their electrical charges ( $\mathrm{pH}-8.8$ ). The separation of the band is aided by electrophoretic and electroendosmotic forces. The agarose gel was loaded with test sample with the help of applicators, and the remainder of the steps were automated. Subsequently, the gel was loaded on to the SAS-2 apparatus. In this, the steps of staining, destaining, and drying were automated. The analysis was performed by scanning the gel using software from Helena Biosciences Europe software PT, version 3.0. The resolution was obtained as six bands: albumin, alpha-1 globulins, alpha- 2 globulins, beta- 1 globulins, beta- 2 globulins, and gamma globulins. Data including clinical findings, biochemical parameters, and hemogram were recovered from the medical records of each patient.

\section{Results}

There were a total 39,900 SPEPs performed and 40 cases of bisalbuminemia were diagnosed over a span of 8 years. The incidence of bisalbuminemia in our cohort was $0.01 \%$ $(1: 1,000)$. The mean age was 52.2 years (range $13-85$ years). There was male preponderance with 13 females and 27 males. The clinicopathological details of all the cases have been highlighted in - Table 1. Patients presented with variable clinical features. The mean hemoglobin was $9.3 \mathrm{~g} / \mathrm{dL}$ (6.8-12.1 g/dL). Diabetes mellitus (DM) was the most common co-existing clinical condition with bisalbuminemia in our cohort $(n=6)$, followed by tuberculosis $(n=3)$ and multiple myeloma $(n=3)$. Other less common co-existing conditions were liver cirrhosis, lung abscess, chronic kidney disease (CKD), acute kidney injury, nephrotic syndrome, dengue, and lung adenocarcinoma.

On electrophoresis, all the cases showed presence of two bands in the albumin region. In addition, mild hypergammaglobulinemia was seen in 13 cases, moderate hypergammaglobulinemia in three cases, and marked hypergammaglobulinemia in two cases. There were 18 cases where the electrophoretic pattern was observed to be normal. There was increased expression of alpha 2 globulins in four cases. There was coexistence of myeloma protein ( $\mathrm{M}$ band) in three cases ( - Fig. 1). Another case demonstrated bisalbuminuria in addition to bisalbuminemia ( - Fig. 2).

\section{Discussion}

This infrequently detected overtly nonpathogenic finding can be either acquired or inherited. The hereditary bisalbuminemia is permanent and reflects the coexistence of two types of albumin. Overall, it has rare consequences in terms of morbidity, but some variants may have a different affinity from that of albumin to normal hormones, metal ions, fatty acids, or drugs. ${ }^{7,8}$ Conversely, the acquired bisalbuminemia occurs as a transitory phenomenon and shows a faster mobility toward the anode as compared with normal albumin. This variance reflects the presence of a normal albumin and a modified albumin. They result from structural changes of a portion of albumin circulating either by addition or subtraction of material. ${ }^{8}$ Other causes include DM, Waldenstrom macroglobulinemia, multiple myeloma, sarcoidosis, pancreatic pseudocyst, nephrotic syndrome, CKD, and in patients on high doses of penicillin. ${ }^{9-12}$ In pancreatic pseudocyst, protein lysis by pancreatic enzymes would be responsible for the double peak. ${ }^{10}$ The beta-lactams can bind to albumin and change its electrophoretic migration. ${ }^{13}$ Diabetes has been associated with bisalbuminemia, though the exact cause is

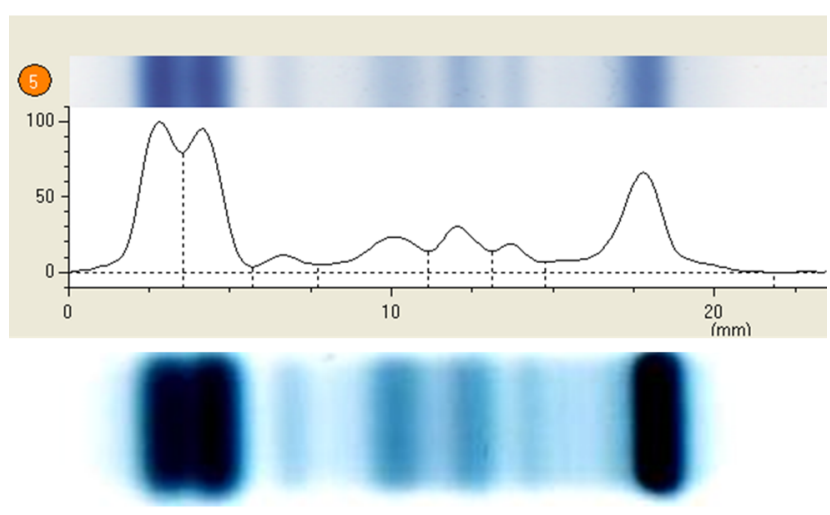

Fig. 1 Densitometer tracing showing two peaks in the albumin region and $\mathrm{M}$ band on serum electrophoresis along with gel picture of bisalbuminemia with $\mathrm{M}$ band.

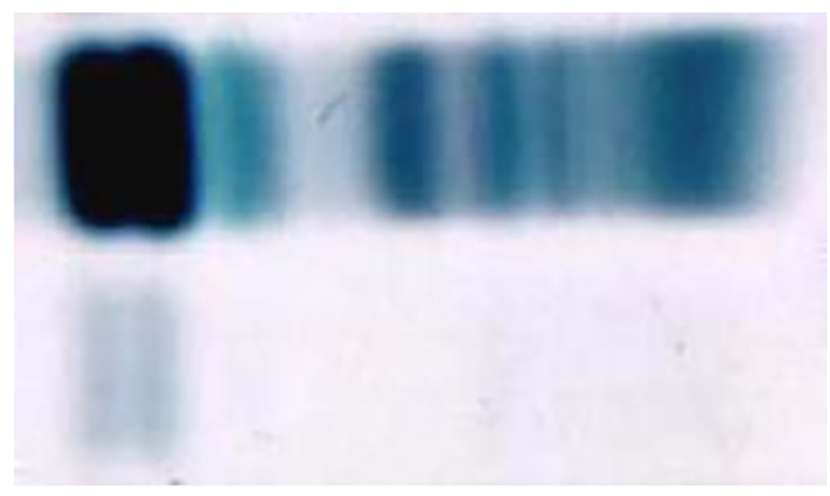

Fig. 2 Serum and urine electrophoresis gel showing bisalbuminemia and bisalbuminuria, respectively. 
Table 1 Clinical and SPEP findings of all the cases

\begin{tabular}{|c|c|c|c|c|}
\hline S. no. & Age (in years) & Sex & Clinical history & $\begin{array}{l}\text { SPEP findings in addition to } \\
\text { bisalbuminemia }\end{array}$ \\
\hline 1 & 28 & Female & $\begin{array}{l}\text { Cirrhosis with portal hypertension, chronic } \\
\text { Budd Chiari syndrome, ascites, vitamin D } \\
\text { deficiency }\end{array}$ & Mild hypergammaglobulinemia \\
\hline 2 & 42 & Male & Lung abscess, fever, cough & Mild hypergammaglobulinemia \\
\hline 3 & 38 & Male & & Marked hypergammaglobulinemia \\
\hline 4 & 52 & Female & $\begin{array}{l}\text { Chronic kidney disease, hypertension, swell- } \\
\text { ing of body }\end{array}$ & Normal pattern \\
\hline 5 & 30 & Female & & Mild hypergammaglobulinemia \\
\hline 6 & 55 & Male & $\begin{array}{l}\text { Primary hyperthyroidism, acute kidney injury, } \\
\text { hypertension, alcoholic liver disease, contrast } \\
\text { nephropathy }\end{array}$ & Mild prominence of alpha 2 globulins \\
\hline 7 & 55 & Male & & Mild hypergammaglobulinemia \\
\hline 8 & 85 & Male & Diabetes mellitus, diabetic nephropathy & Moderate hypergammaglobulinemia \\
\hline 9 & 56 & Male & Distal neuropathy & Normal pattern \\
\hline 10 & 50 & Female & Hypercalcemia and renal failure & $\begin{array}{l}\text { Mild hypergammaglobulinemia and mild } \\
\text { prominence of alpha } 2 \text { globulins }\end{array}$ \\
\hline 11 & 64 & Male & & Normal pattern \\
\hline 12 & 48 & Male & ? Amyloidosis & Normal pattern \\
\hline 13 & 57 & Male & Hypertension, nephrotic syndrome & Normal pattern \\
\hline 14 & 67 & Male & Tuberculosis, fever, cough & Mild hypergammaglobulinemia \\
\hline 15 & 50 & Female & $\begin{array}{l}\text { Tuberculosis, pericardial effusion, DVT, fever } \\
\text { with cough }\end{array}$ & Normal pattern \\
\hline 16 & 70 & Male & Multiple myeloma & $\begin{array}{l}\mathrm{M} \text { band in gamma region in background of } \\
\text { marked hypogammaglobulinemia }\end{array}$ \\
\hline 17 & 56 & Male & $\begin{array}{l}\text { Rapidly progressive renal failure with increase } \\
\text { in creatinine }\end{array}$ & Mild hypergammaglobulinemia \\
\hline 18 & 66 & Female & & Normal pattern \\
\hline 19 & 45 & Male & Brachial plexopathy, diabetes mellitus & Normal pattern \\
\hline 20 & 55 & Male & & Normal pattern \\
\hline 21 & 70 & Female & $\begin{array}{l}\text { Metastatic adenocarcinoma with pleural } \\
\text { and pericardial effusion and lymphocytic } \\
\text { thyroiditis }\end{array}$ & $\begin{array}{l}\text { Mild prominence of alpha } 2 \text { globulins and } \\
\text { moderate hypergammaglobulinemia }\end{array}$ \\
\hline 22 & 55 & Male & & Normal pattern \\
\hline 23 & 57 & Male & $\begin{array}{l}\text { Hypertension, diabetes mellitus with pedal } \\
\text { edema }\end{array}$ & Mild hypergammaglobulinemia \\
\hline 24 & 40 & Male & & Normal pattern \\
\hline 25 & 52 & Male & Tuberculosis & Moderate hypergammaglobulinemia \\
\hline 26 & 58 & Male & & Normal pattern \\
\hline 27 & 40 & Female & Cryoglobulinemic vasculitis & Normal pattern \\
\hline 28 & 61 & Male & & $\begin{array}{l}\text { Mild hypergammaglobulinemia along with } \\
\text { bisalbuminuria }\end{array}$ \\
\hline 29 & 62 & Male & $\begin{array}{l}\text { Diabetes mellitus with chronic inflammatory } \\
\text { demyelinating neuropathy }\end{array}$ & Normal pattern \\
\hline 30 & 49 & Male & Hypertension, diabetes mellitus & Mild hypergammaglobulinemia \\
\hline 31 & 50 & Male & & Normal pattern \\
\hline 32 & 42 & Male & & Normal pattern \\
\hline 33 & 65 & Female & Diabetes mellitus & Normal pattern \\
\hline 34 & 60 & Female & Previous known case of multiple myeloma & Mild hypergammaglobulinemia \\
\hline
\end{tabular}


Table 1 (Continued)

\begin{tabular}{|l|l|l|l|l|}
\hline S. no. & Age (in years) & Sex & Clinical history & $\begin{array}{l}\text { SPEP findings in addition to } \\
\text { bisalbuminemia }\end{array}$ \\
\hline 35 & 51 & Male & & Normal pattern \\
\hline 36 & 45 & Female & ? Multiple myeloma (anemia and renal failure) & Mild hypergammaglobulinemia \\
\hline 37 & 53 & Female & Renal failure & Mild hypergammaglobulinemia \\
\hline 38 & 51 & Male & $\begin{array}{l}\text { ? Multiple myeloma (anemia, renal failure, } \\
\text { fatigue, backache) }\end{array}$ & $\begin{array}{l}\text { M band in gamma region in background of } \\
\text { normal gamma globulins }\end{array}$ \\
\hline 39 & 45 & Female & ? Multiple myeloma & $\begin{array}{l}\text { M band in gamma region in background of } \\
\text { marked hypogammaglobulinemia }\end{array}$ \\
\hline 40 & 13 & Male & Dengue with ? Reactive arthritis & $\begin{array}{l}\text { Mild prominence of alpha 2 globulins and } \\
\text { marked hypergammaglobulinemia }\end{array}$ \\
\hline
\end{tabular}

Abbreviations: DVT, deep vein thrombosis; SPEP, serum protein electrophoresis. ? denotes possible diagnosis

not known. ${ }^{14}$ Monoclonal gammopathies including myelomas may be randomly seen with bisalbuminemia, ${ }^{15}$ though nobody talks about the reason for the same. Chan et $\mathrm{al}^{16}$ found that bisalbuminemia is a rare incidental finding in monoclonal gammopathies and is not associated with the same. Bisalbuminuria is a rarer finding which shows two distinct fractions of urinary albumin on electrophoresis. There are just few case reports of the same. ${ }^{17,18}$ We have also described one case in our series which showed both bisalbuminemia and bisalbuminuria.

When we see inherited types, one demonstrates either slow (with less negative net charge) or fast (with more negative net charge) electrophoretic mobility. ${ }^{19}$ Contrastingly, the acquired form displays presence of albumin dimers-an extra band in the immediate post-albumin region signifying 10 to $15 \%$ of the total albumin fraction. Inherited forms may show single point (e.g., arginyl-albumin resulting from the substitution of arginine [Arg] in place of normal amino-terminal aspartic acid moiety) or chain-termination mutations (a mutation in the amino-terminal Arg-Arg propeptide sequence required for post-transcriptional processing of albumin) ${ }^{20}$ In our cohort, there is predominant North Indian population admixed with Caucasian population. In our population cohort, there does not seem to be any association due to variable presentation. Therefore, bisalbuminemia is not a product of any disease but a chance finding which could be attributed to possibly hereditary type.

Albumin variations, as detected on SPEP, should keenly be noticed by both the clinicians and immunopathologists. Such novel forms of albumin may also offer data on evolution, molecular structure, and characteristics of the albumin molecule. Acquired form should arouse suspicion and make clinician think if there is any underlying disease process going on which is not diagnosed yet. Learning about albumin variants can be of great inquisitiveness and might be valuable in assessing their geographical distribution. There is no well-known clinical importance of this entity except stated above. It should not be mistaken as an abnormal globulin peak specially while seeing suspected or confirmed cases of monoclonal gammopathies. These bands usually vanish after the stoppage of drug or the treatment of disease. ${ }^{21,22}$ Some of the albumin variants show altered affinity for several ligands, like steroidal hormones, thyroxine, and many drugs. ${ }^{21,23,24}$ Therefore, it is important to recognize such variants which may further provide more knowledge about the nature of diseases related with atypical binding of these ligands to albumin. Clinicians and immunopathologists must keep this entity in their radar and interpret it with caution.

\section{Conflict of Interest}

None declared.

\section{References}

1 Peters T Jr, All About Albumin: Biochemistry, Genetics and Medical Applications. San Diego, CA: Academic Press; 1996

2 Kragh-Hansen U, Minchiotti L, Galliano M. Peters $\mathrm{T}$ Jr. Human serum albumin isoforms: genetic and molecular aspects and functional consequences. Biochim Biophys Acta 2013;1830(12):5405-5417

3 Ha CE, Bhagavan NV. Novel insights into the pleiotropic effects of human serum albumin in health and disease. Biochim Biophys Acta 2013;1830(12):5486-5493

$4 \mathrm{Kim}$ YH, Lee YW, Jeon BR, et al. Clinical characteristics and ALB gene mutation analysis of Korean patients with bisalbuminemia. Korean J Lab Med 2010;30(3):307-311

5 Takahashi N, Takahashi Y, Isobe T, et al. Amino acid substitutions in inherited albumin variants from Amerindian and Japanese populations. Proc Natl Acad Sci U S A 1987;84(22):8001-8005

6 Sharma S, Gupta P, Aggarwal R, Malhotra P, Minz RW, Bansal F. Demystifying biclonal gammopathy: a pathologist's perspective. Lab Med 2019;50(4):357-363

7 AvRuskin TW, Juan CS, Weiss RE. Familial dysalbuminemic hyperthyroxinemia: a rare example of albumin polymorphism and its rapid molecular diagnosis. J Pediatr Endocrinol Metab 2002;15(6):801-807

8 Tance Y, Deneuville T, Tiev KP, et al. Un pic transitoire sur l'électrophorèse des protides sériques. Rev Med Interne 2009;30(5):436-437

9 Šimundić A, Miler M, Nikolac N, et al. Bisalbuminemia in a male Croatian patient with sarcoidosis. Biochem Med (Zagreb) 2009;19:95-100

10 Ejaz AA, Krishna M, Wasiluk A, Knight JD. Bisalbuminemia in chronic kidney disease. Clin Exp Nephrol 2004;8(3):270-273

11 Kalambokis G, Kitsanou M, Kalogera C, Kolios G, Seferiadis K, Tsianos E. Inherited bisalbuminemia with benign monoclonal 
gammopathy detected by capillary but not agarose gel electrophoresis. Clin Chem 2002;48(11):2076-2077

12 Shetty JK, Prakash M, Gopalakrishna K. Bisalbuminemia in an adult male with Alzheimer's disease. Indian J Med Sci 2007;61(6):356-357

13 Winter V, Rosenvall A, Heikkilä S, von Essen R. Acquired bisalbuminemia in staphylococcal endocarditis treated with dicloxacillin. Scand J Infect Dis 1992;24(6):811-814

14 Shetty JK, Maradi R, Prabhu K, Bhat G. Bisalbuminemia in a hypothyroid patient with diabetes: a case report. J Clin Diagn Res 2015;9(9):BD01-BD02

15 Pola V, Tichý M. Bisalbuminemia. Critical review and report of a case of an acquired form in a myeloma patient. Folia Haematol Int Mag Klin Morphol Blutforsch 1985;112(1):208-218

16 Chan PC, Yasodhara A, Truong D. Bisalbuminemia: lack of association with monoclonal gammopathy and value-justification for reporting in serum protein electrophoresis. J Clin Chem Lab Med 2017; 1:108

17 Hoang MP, Baskin LB, Wians FH Jr. Bisalbuminuria in an adult with bisalbuminemia and nephrotic syndrome. Clin Chim Acta 1999;284(1):101-107
18 Al-Sarraf A, Chow C, Garg A. Bisalbuminuria detected by agarose gel electrophoresis. Clin Biochem 2010;43(4-5):534-536

19 Jamieson GA, Ganguly P. Studies on a genetically determined albumin dimer. Biochem Genet 1969;3(4):403-416

20 Faviou E, Nounopoulos C, Dionyssiou-Asteriou A. Bisalbuminemia from a clinical chemist's viewpoint: a case report and review of the recent literature. Minerva Med 2006;97(3):287-293

21 Arvan DA, Blumberg BS, Melartin L. Transient "bisalmuminemia" induced by drugs. Clin Chim Acta 1968;22(2):211-218

22 Kobayashi S, Okamura N, Kamoi K, Sugita O. Bisalbumin (fast and slow type) induced by human pancreatic juice. Ann Clin Biochem 1995;32(Pt 1 ) :63-67

23 Kragh-Hansen U, Minchiotti L, Brennan SO, Sugita O. Hormone binding to natural mutants of human serum albumin. Eur J Biochem 1990;193(1):169-174

24 Kragh-Hansen U, Brennan SO, Galliano M, Sugita O. Binding of warfarin, salicylate, and diazepam to genetic variants of human serum albumin with known mutations. Mol Pharmacol 1990;37(2):238-242 